\title{
Antioxidant activity test of ethyl acetate total extract from Batak leeks (Allium chinense G. Don)
}

\author{
Aliyah Fahmi ${ }^{1,{ }^{*}}$, Hamelasari Sitompul ${ }^{1}$ \\ 'Pharmacy Study Program, Faculty of Health, Universitas Efarina, Pematang Siantar, Indonesia \\ ${ }^{*}$ Corresponding author: (AF); Faradisty@yahoo.com
}

\begin{abstract}
:
The research with titled "Antioxidant activity test of ethyl acetate total extract from Batak leeks (Allium. chinense G. Don)" had been done. For the antioxidant activity test using UV Visible Spectrophotometer with 2,2-diphenyl-1-picrylhydrazyl (DPPH) as a scavenging agent obtained $\mathrm{IC}_{50}$ ethyl acetate extract total batak leeks amounted to $52.39 \% \mathrm{mg} / \mathrm{L}$ which stated that the extract was strong antioxidant.
\end{abstract}

Keywords:

Activities; antioxidants; Batak leeks

\section{Introduction}

One of the famous genus of plants that is widely used by the community is Bawang or Allium. The Allium genus consists of more than 280 species spread throughout the world (Robinowitch and Currah, 2002). Most of this genus is used by the community as a spice in cooking and traditional medicine. Allium is widely used as an antimicrobial and antifungal. In addition, Allium is also used in food preservation to replace chemical compounds that are widely used in the food industry. Various antimicrobial compounds of this genus have long been known as allicin, diallyl disulfide, ajoene, and 3-(Allyltrisulfanyl) -2- amino-propanoic acid. Allium plants can inhibit the growth of microorganisms such as bacteria, fungi, viruses and parasites (Kyung, 2012).

One of the species of Allium which is a typical plant of North Sumatra, especially the Batak tribe is the Batak onion or Lokio ( $A$. Chinense G. Don or A. schoenoprasum $L$ (chives)). Chives are like the onions, but with the tip of a longer stalk and the color tends to be white. So it resembles a petite onion with long small leaves, and also looks like an onion, but its size is much smaller, often considered the same as Chives, but different. Chives (Allium tuberosum Rottler ex Spreng. And A. ramosus) are known as leaf vegetables(Fig 1).

With the diversity of medicinal plants, there are several plants that have the same name, although different. That's because some plants have not been fully identified. One of them is Batak onion ( $A$. chinense G. Don) which is a typical plant from North Sumatra which is widely used as a spice in cooking. In addition, the benefits of these batak leeks include good for eye health, prevent premature aging, a source of vitamin $\mathrm{K}$, increase fertility, prevent thrush, rich in minerals, help the diet, neutralize toxins, balance blood sugar, overcome constipation and can prevent cancer (Bah et al. 2012).

Several studies on batak leaves which have been carried out include: phytochemical screening and antimicrobial test of Batak onion rough extract (Allium chinense) (Rubiatik et al. 2015), and antimicrobial activity of Allium Chinense G. Don (Naibaho et al. 2015). The main reason the 
researchers wanted to remove these leeks was because in addition to the typical North Sumatra plant, research on these onions still needed to be developed given the enormous benefits of these onions (Aretha and Jusuf, 2019).

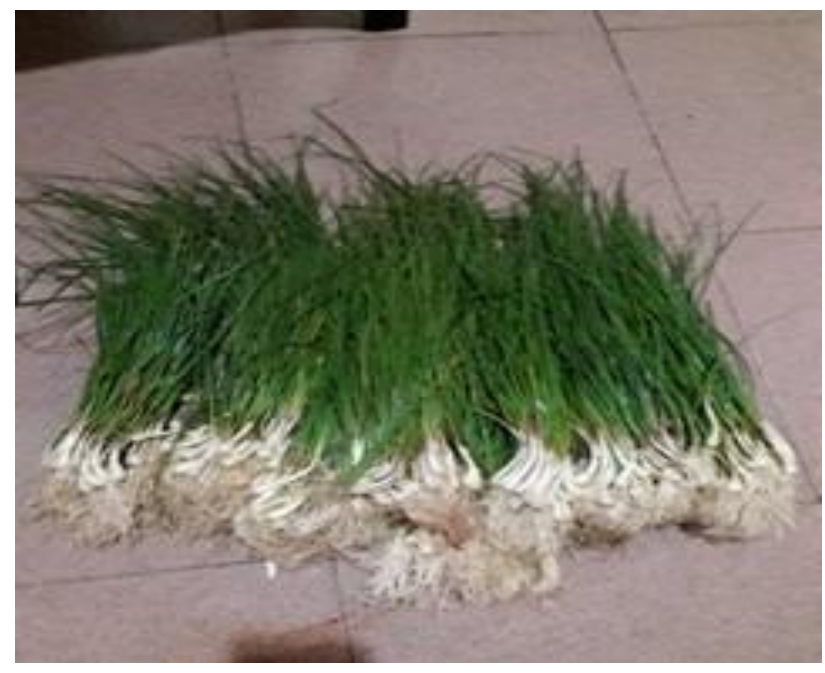

Fig 1. Batak onion plants (Allium chinense G. Don)

\section{Materials and Methods}

\section{Materials}

The materials used in this study include: Leek onion ( $A$. chinense G. Don), Methanol pa (Merck), DPPH (Sigma Aldrich), Vitamin C pa (Merck), Technical Methanol, Technical Hexane N, Technical Ethyl Acetate.

\section{Preparation sample}

Batak leeks ( $A$. chinense G. Don) were collected from Batak onion plantations in the Lake Toba area purposively (not comparing with other regions) as a sample. Batak leeks were cleaned, weighed and dried. The dried sample was blended using a blender. Then as much as $400 \mathrm{~g}$ of Batak leeks powder put into Erlenmeyer glass added with $1 \mathrm{~L}$ of methanol. Macerated for $1 \times 24$ hours at room temperature. Filtered the macerate and separated with the residual until the solvent was colored clear and then evaporated with a Rotary Evaporator under vacuum until a thick extract was obtained. The thick extract was evaporated until the solvent completely evaporated and the concentrated methanol extract of the Batak leeks was obtained (Ditjen POM, 1995). Furthermore, the concentrated extract of Batak leek was dissolved with ethyl acetate, filtered with separated from the residue, then the filtrate was evaporated again until the solvent completely evaporated so that the ethyl acetate extract of the Batak leeks was dissolved again with methanol until completely dissolved and in a partition with $\mathrm{n}$-hexane formed two layers, taken the bottom layer and evaporated until total ethyl acetate extract was obtained.

\section{Antioxidant activity test of ethyl acetate extract of Batak leek}

$2 \mathrm{~mL}$ of DPPH $200 \mathrm{ppm}$ solution was added and diluted with sample until mark line in $10 \mathrm{~mL}$ measuring flask, gently rocking until homogeneous then incubated in dark room for 30 minutes. The absorbance was measured at a maximum $\lambda$ of $516 \mathrm{~nm}$ using a Visible UV Spectrophotometer Shimadzu 1800. Saved results obtained. Three repetitions were performed. Did the same procedure to ascorbic acid as positive blank (Fahmi, 2016). 


\section{Results}

\section{Preparation sample}

The initial weight of fresh batak leeks were $10.000 \mathrm{~g}$, allowed to dry until the leeks could be kneaded in the room ( \pm 2 weeks) and weighed $420 \mathrm{~g}$ or $4.2 \%$. Then weighed $400 \mathrm{~g}$ of onion batak leeks powder to be extracted obtained thick methanol extract of $48.9 \mathrm{~g}$ of batak leeks or as much as $0.489 \%$ then extracted with ethyl acetate and partitioned with $\mathrm{n}$-hexane where the bottom layer was evaporated weighing $2 \mathrm{~g}$ or $0.02 \%$.

\section{Antioxidant activity test of ethyl acetate extract total Batak leeks}

Presented below was the antioxidant activity test table with the DPPH blank (vitamin C; ascorbic acid) method and methanol extract and ethyl acetate extract of total batak leeks using a UV Visible spectrophotometer Shimadzu 1800.

Percentage of DPPH scavenging at a wavelength of $516 \mathrm{~nm}$ to vitamin $\mathrm{C}$ with a concentration of $100 \mathrm{ppm}$ was very strong at $93.11 \%$, this illustrated that vitamin $C$ had a strong free radical inhibitory activity and was suitable for use as a positive blank which shown on Table 1. Percentage of DPPH scavenging at a wavelength of $516 \mathrm{~nm}$ to ethyl acetate total extract of Batak Leeks with a concentration of $100 \mathrm{ppm}$ was strong enough at $22.32 \%$ which shown on Table 2. From the above data presented the antioxidant activity test as shown in Fig 2.

Table 1

Tests of antioxidant activity of positive blank of ascorbic acid (vitamin C)

\begin{tabular}{llll}
\hline No & $\begin{array}{l}\text { Concentration } \\
(\mu \mathrm{g} / \mathrm{ml})\end{array}$ & $\begin{array}{l}\text { Absorbance } \\
(\mathrm{A})\end{array}$ & $\begin{array}{l}\text { Effect Scavenging } \\
(\%)\end{array}$ \\
\hline 1 & 0 & 0.9473 & 0 \\
2 & 20 & 0.0802 & 91.53 \\
3 & 40 & 0.0717 & 92.43 \\
4 & 60 & 0.0677 & 92.85 \\
5 & 80 & 0.0658 & 93.05 \\
6 & 100 & 0.0652 & 93.11 \\
\hline
\end{tabular}

Table 2

Test of antioxidant activity of Batak leek ethyl acetate total extract

\begin{tabular}{llll}
\hline No & $\begin{array}{l}\text { Concentration } \\
(\mu \mathrm{g} / \mathrm{ml})\end{array}$ & $\begin{array}{l}\text { Absorbance } \\
(\mathrm{A})\end{array}$ & $\begin{array}{l}\text { Effect Scavenging } \\
(\%)\end{array}$ \\
\hline 1 & 0 & 1.0629 & 0 \\
2 & 20 & 1.015 & 4.50 \\
3 & 40 & 0.99 & 6.86 \\
4 & 60 & 0.9307 & 12.44 \\
5 & 80 & 0.8808 & 17.13 \\
6 & 100 & 0.8257 & 22.32 \\
\hline
\end{tabular}

A sample of fresh batak leeks with an initial weight of $10.000 \mathrm{~g}$. Then the sample was allowed to dry and re-weighed as the final weight, $420 \mathrm{~g}$ or $4.2 \%$. The extract did not contain any residual solvents, therefore the drying losses were identical to those of the water content, so the extract produced in this study was a thick extract which was tough in the cold, difficult to pour and the percentage of water content was 5-30\% (Depkes Rl, 2000). Thick methanol extract of batak leek 
was $48.9 \mathrm{~g}$ or equal to $0.489 \%$. The total ethyl acetate extract was $2 \mathrm{~g}$ or $0.002 \%$. With the data in Table 1 the equation of the regression line of the antioxidant activity of ascorbic acid as positive blank shown in Table 3.

\section{Table 3}

Equation of linear regression lines

\begin{tabular}{lllll}
\hline Number & $X$ & $Y$ & $X Y$ & X2 \\
\hline 1 & 0 & 0 & 0 & 0 \\
2 & 20 & 91.53 & 1830.6 & 400 \\
3 & 40 & 92.43 & 3697.2 & 1600 \\
4 & 60 & 92.85 & 5571 & 3600 \\
5 & 80 & 93.05 & 7444 & 6400 \\
6 & 100 & 93.11 & 9311 & 10000 \\
total & 300 & 462.97 & 27853.8 & 22000 \\
mean & 50 & 77.1616667 & 4642.3 & 3666.66 \\
\hline
\end{tabular}

Information:

$X=$ Concentration of ascorbic acid; $Y=\%$ scavenging at a wavelength of $516 \mathrm{~nm}$

If a was the intercept (the intersection of the curve with respect to the $Y$ axis) and $b$ was the slope of the linear curve where $Y$ was the dependent variable which stated 50 and $X$ was the independent variable which stated Concentration of Inhibit Concentration then $Y=a X+b$ (Sugiono, 2009).

We counted value for $a=0.67$ and $b=43.55$ and then find out $1 C_{50}$ (Inhibit Concentration 50) with this formula was $9.59 \mathrm{mg} / \mathrm{L}$.

With the data in Table 2 the equation of the regression line of the antioxidant activity of ethyl acetate extracts the total of the Batak leeks were obtained as shown in Table 4.

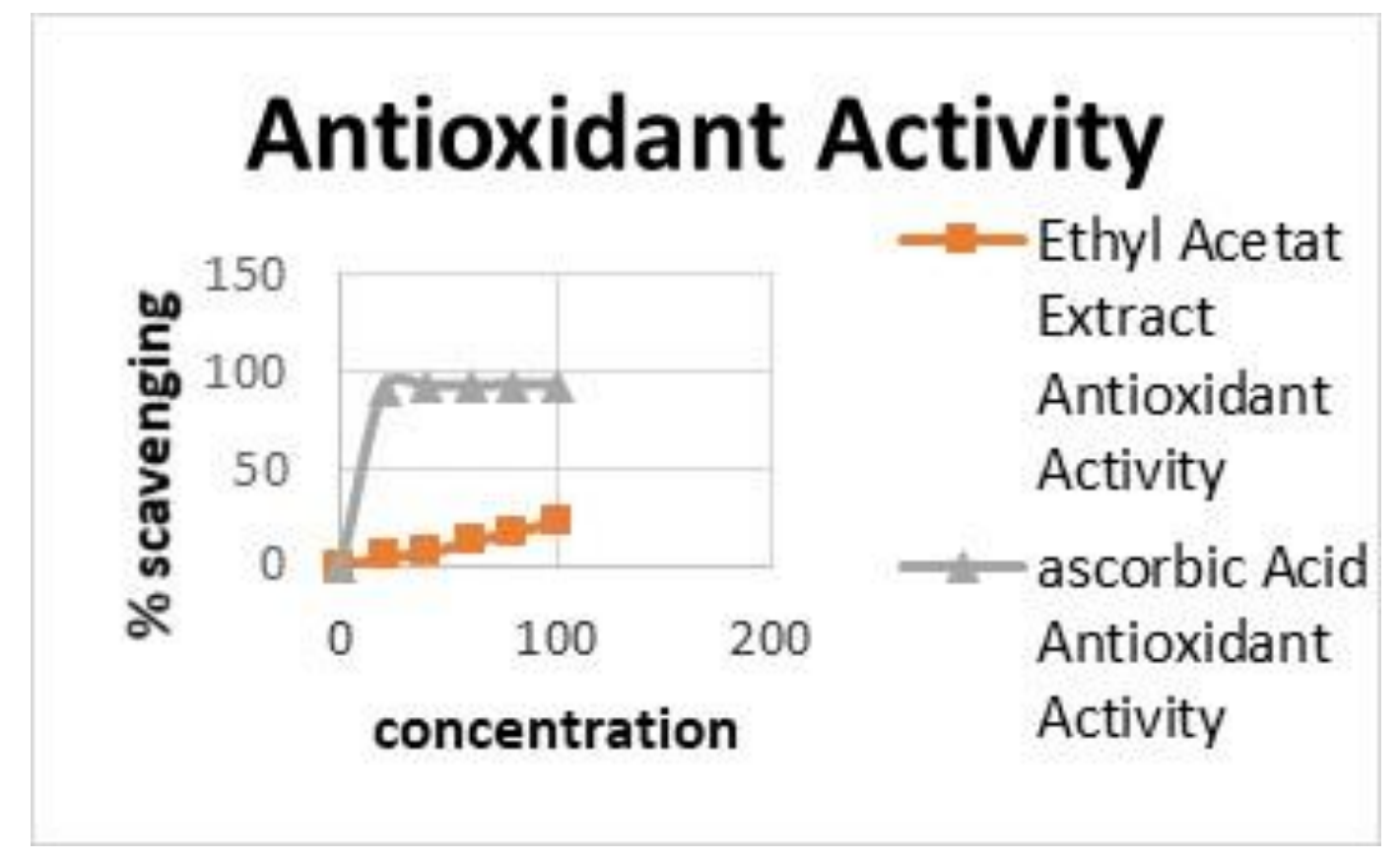

Fig 2. Graph $X$ as concentration versus $Y$ as percent of scavenging by DPPH 
Table 4

Equation of linear regression lines

\begin{tabular}{lllll} 
Number & $\mathbf{X}$ & $\mathrm{Y}$ & $\mathrm{XY}$ & $\mathbf{X 2}$ \\
\hline 1 & 0 & 0 & 0 & 0 \\
2 & 20 & 4.51 & 90.2 & 400 \\
3 & 40 & 6.86 & 274.4 & 1600 \\
4 & 60 & 12.43 & 745.8 & 3600 \\
5 & 80 & 17.13 & 1370.4 & 6400 \\
6 & 100 & 22.31 & 2231 & 10000 \\
total & 300 & 63.24 & 4711.8 & 22000 \\
mean & 50 & 10.54 & 785.3 & 3666.667 \\
\hline
\end{tabular}

Notes:

$\mathrm{X}=$ total concentration of ethyl acetate extract on batak leeks; $\mathrm{Y}=\%$ scavenging at a wavelength of $516 \mathrm{~nm}$ With same formula, we could count value for $\mathrm{a}=0.22 \mathrm{dan} \mathrm{b}=-0.53$ then find out $\mathrm{IC}_{50}$ (Inhibit Concentration 50) with this formula was $52.39 \mathrm{mg} / \mathrm{L}$.

\section{Discussion}

The method used to test the antioxidant activity of total ethyl acetate in batak leeks were a test method using DPPH free radicals because the equivalent gives $50 \%$ inhibitory concentration as an antioxidant activity $\left(\mathrm{IC}_{50}\right)$. DPPH was a stable free radical that reacted with compounds that could donate hydrogen atoms, can be useful for testing the antioxidant activity of certain components in an extract because it had unpaired electrons, DPPH provided strong absorption at wavelengths of 515-517 $\mathrm{nm}$. When the electrons become paired, the absorbance decreased stoichiometrically according to the number of electrons taken. The presence of antioxidant compounds could change the color of DPPH solution from purple to yellow (Dehpour et al. 2009; Febrina et al. 2017; Simorangkir et al. 2019) as shown in Fig 3. From the data, it was concluded that the ethyl acetate extract of batak leeks had strong antioxidant activity of $52.39 \mathrm{mg} / \mathrm{L}$. According to Pokorny et al. (2001) $\mathrm{IC}_{50}$ value was strong if $\mathrm{IC}_{50}$ between $50-100 \mathrm{mg} / \mathrm{L}$.

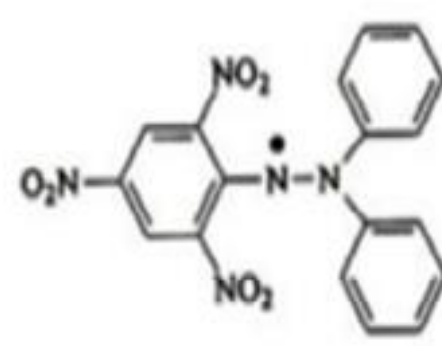

Left (The radical D:PH with purple colour)
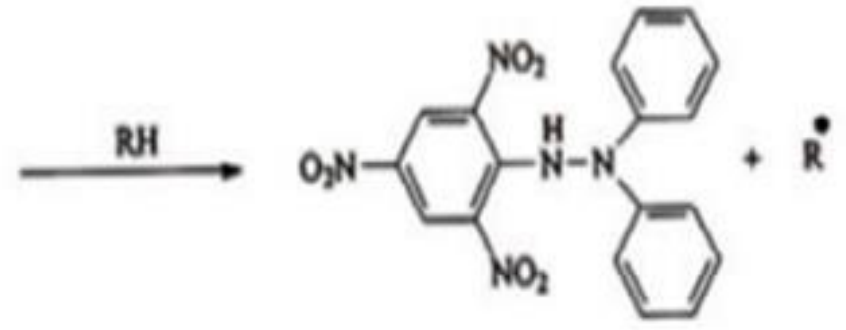

Right ( The stable DPPH with yellow colour)

Fig 3. DPPH Mechanism (Yuhernita and Juniarti, 2011)

\section{Conclusion}

From the results of research conducted on Batak leek could be concluded as follows that for the test of the antioxidant activity of ethyl acetate extracts of batak leek with DPPH 200 ppm as measured by UV Visible Spectrophotometer at maximum wavelength of $516 \mathrm{~nm}$ obtained $1 \mathrm{C}_{50}$ of 
$52.4 \mathrm{mg} / \mathrm{L}$ while vitamin $\mathrm{C}$ as $\mathrm{IC}_{50}$ positive blank was $9.59 \mathrm{mg} / \mathrm{L}$ and with the highest percentage of scavenging at each concentration of $100 \mathrm{ppm}$.

\section{Acknowledgments}

This work was supported by grant "Penelitian Dosen Pemula Year 2019" from the ministry of research and higher education of the Indonesia Republic for funding this collaboration (RISTEKDIKTI).

\section{References}

Aretha, T., and Jusuf, N. K. (2019). In vitro antimicrobial activity of bawang Batak bulbs (Allium Chinense G. Don) against methicillin-resistant Staphylococcus Aureus. Sumatera Medical Journal, 2(2), 13-17.

Bah, A.A., Wang, F., Huang, Z., Shamsi, I.H., Zhang, Q., Jilani, G., Hussain, S., Hussain, N., and Ali, E. (2012). Phyto-characteristics, cultivation and medicinal prospects of Chinese jiaotou (Allium chinense). Int. J. Agric. Biol., 14, 650-657.

Dehpour, A. A., Ebrahimzadeh, M. A., Fazel, N. S., \& Mohammad, N. S. (2009). Antioxidant activity of the methanol extract of Ferula assafoetida and its essential oil composition. Grasas y Aceites, 60(4), 405-412, doi: 10.3989/gya.010109

Depkes Rl. (2000). Parameter standar umum ekstrak tumbuhan obat. Jakarta: Departemen Kesehatan Rl. Hal. 1

Ditjen POM. (1995). Farmakope Indonesia. Edisi IV. Departemen Kesehatan Rl. Jakarta

Fahmi, A. (2016). Uji aktivitas antioksidan dan toksisitas serta antimikroba dari flavonoid total daun benalu (Dendrophthoe pentandra (L.) Miq) pohon glodokan (Polyalthia longifolia). (Master's thesis) USU Repository Medan.

Febrina, L., Riris, 1. D., \& Silaban, S. (2017). Activity antibacterial to Escherichia coli and antioxsidant of extract water of leaf binara plant (Artemisia vulgaris L.) after blanching. Jurnal Pendidikan Kimia, 9(2), 311-317, doi:10.24114/jpkim.v9i2.7621

Kyung, K. H. (2012). Antimicrobial properties of allium species. Current Opinion in Biotechnology, 23(2), 142-147, doi: 10.1016/j.copbio.2011.08.004

Naibaho, F. G. (2015). Aktivitas antimikrob dan identifikasi senyawa bioaktif ekstrak bawang batak (Allium chinense G. Don.) [tesis]. Bogor (ID): Institut Pertanian Bogor.

Pokorny, J., Yanishlieva, N., and Gordon, M. H. (Eds.). (2001). Antioxidants in food: practical applications. CRC press.

Robinowitch, H.D., and Currah, L. (2002). Allium Crop Science: Recent Advances. New York: CABI Publishing

Rubiatik, S., Sartini, S., and Lubis, R. (2017). Skrining fitokimia dan uji antimikroba ekstrak kasar bawang Batak (Allium cinense) terhadap bakteri Staphylococcus aureus dan Escherichia coli. BIOLINK (Jurnal Biologi Lingkungan, Industri, Kesehatan), 2(1), 1-9.

Simorangkir, M., Hutabarat, W., Nainggolan, B., and Silaban, S. (2019). Antioxidant and antibacterial activities of nonpolar to polar solvent extracts of Sarang Banua (Clerodenrum fragrans Vent Willd) leaves. Rasayan Journal of Chemistry, 12(02), 959-965, doi: 10.31788/rjc.2019.1225095

Sugiono, D. R. (2009). Statistika Untuk Penelitian. Penerbit CV. Alfabeta. Bandung. Jawa Barat.

Yuhernita and Juniarti. (2011). Analisis senyawa metabolit sekunder dari ekstrak metanol daun surian yang berpotensi sebagai antioksidan. Makara Journal of Science, 15(1), 48-52, doi: 10.7454/mss.v15il.877 